\title{
An Empirical Study on the Influence of Perceived Organizational Support on Academic Expatriates' Organizational Commitment
}

\author{
Khulida Kirana Yahya ${ }^{1}$, Fairuzah Zaharos Mansor $^{2}$ and Ari Warokka ${ }^{3}$ \\ ${ }^{1}$ College of Business - Universiti Utara Malaysia, Malaysia \\ ${ }^{2}$ Universiti Teknologi MARA - Malaysia, Malaysia \\ ${ }^{3}$ Othman Yeop Abdullah Graduate School of Business - UUM, Malaysia
}

\begin{abstract}
The paper aims to examine the relationships between the perceived organizational support and expatriates' organizational commitment. A total of 131 questionnaires was distributed to expatriate who are currently serving at a public university and a sample of 93 returned-questionnaires was used for further analysis. The data were analyzed using Pearson's correlation and regression analysis to investigate the relationship perceived organizational support and organizational commitment. The correlation analysis proved that the perceived organizational support was highly important to affective and normative commitment whereas its relationship with continuance commitment is not relevant. Finally, the regression analysis revealed perceived organizational support as being more significant at influencing organizational commitment. Furthermore, the regression results also showed that $40.6 \%$ of total variance of POS was explained by organizational commitment. This denotes that POS play a vital role in promoting organizational commitment. In addition, discussions, implications, as well as conclusions of the study were also highlighted.
\end{abstract}

Keywords: Perceived organizational support, organizational commitment, academic expatriate.

\section{Introduction}

Education in Malaysia has been a driving force to cope with global challenges faced by the country as well as contributing to the nation's aspiration of becoming a developed country. Malaysia sees quality of education as directly related to the strength of the economy (Prime Minister of Malaysia, 2009). A critical success factor for the highereducation transformation education transformation in Malaysia is the transfer of knowledge. In the case of Malaysia, it has resulted in a trigger effect of employing international faculty or expatriates to help boost the standard of higher-education level in Malaysia. Therefore, expatriate adjustment and ultimately performance is vital to the success of this strategy. It was found that job satisfaction is the strongest predictor of expatriate adjustment, and those are able to socialize at the host country are more likely to adjust more effectively to the new environment (Lee, 2005). Socialization in the host country would facilitate expatriates with cross-cultural adjustments faced with at the host country and give them the possibility of being accepted into the group of host country nationals faster compared to their

Copyright (C) 2012 Khulida Kirana Yahya, Fairuzah Zaharos Mansor and Ari Warokka. This is an open access article distributed under the Creative Commons Attribution License unported 3.0, which permits unrestricted use, distribution, and reproduction in any medium, provided that original work is properly cited. Contact author: Khulida Kirana Yahya E-mail: khulida@uum.edu.my 
counterparts who are unable to socialize at the host country.

A recent study of expatriate academic staff in Malaysia found that organizational commitment was positively correlated to job satisfaction and that local or nationals' academic staffs scored higher job satisfaction than their international colleagues did (Hassan \& Hashim, 2011). It was argued that because organizational commitment measures emotional attachment to the organization. Prior empirical findings revealed that the more personal interactional justice had been greater significantly influencing, as a result of the difficulty faced by expatriates to gain in-group membership since they did not belong to the host-country culture (Hassan \& Hashim, 2011). Therefore, expatriates perceived organizational support is redeveloped by their global beliefs that the organization cares about their well-being (Eisenberger, Huntington, Hutchison, \& Sowa, 1986). Perceived organizational support is also seen as an assurance in which supports and assistance "will be available from the organization when it is needed to carry out one's job effectively and to deal with stressful situations" (George, Reed, Ballard, Colin, \& Fielding, 1993).

Previous research also found that organizational support when compared to leader-member exchange and spousal support relates positively to general adjustment, work and interaction adjustment (Kraimer, Wayne, \& Jaworski, 2001). These findings support the argument that organizational support in fact relates to cross-cultural adjustment. Therefore, members of the organization or institution in reality play a key role in assisting the expatriates to make sense of their experience when entering an unfamiliar organization or institution (Louis, 1980).

Nevertheless, the role played by the members of the organization should be seen as a supportive role. It is still the organization that should provide the support to the expatriates since its support actually extends beyond the boundaries of merely the work environment (Kraimer, Wayne, \& Jaworski, 2001). Previous research also found that perceived organizational support was a more significant predictor of organizational commitment than was supervisor support and mentoring (Dawley, Andrews, \& Bucklew, 2008). This is a result of employees being capable of distinguishing between, perceived organizational support and perceived team support (Bishop, Scott, Goldsby, \& Cropanzano, 2005). Employees are able to distinguish that perceived team support plays merely a supporting role, whereas perceived organizational support is from the organization. The difference between the focus of team support and organization support can be seen through the programs it exerts. A common example of team support is mentoring and coaching programs. Subsequently, examples of organizational supported programs could include socialization interventions (Lee, 2005), fair operating procedures, rewards and job conditions (Rhoades \& Eisenberger, 2002).

In the context of Malaysia, international faculty or expatriates are self-initiated expatriates. This means that they voluntarily leave their home country to seek appointment at the host country. They also do not have any ties to the home country. These expatriates are employed on various types of appointment ranging from short term collaborations to contractual appointments with mutually agreed predefined tenures of between 1 to 3 years with subsequent reappointments. The reappointments are subject to their performance and the university's financial standing. However in public universities, the majority of expatriates are appointed on contracts which are guided by the public circulars which are generally known to offer less attractive packages compared to their counterparts appointed at private universities. The private universities are business entities and are profit oriented. The private universities which are doing well would be financially capable of offering its expatriates better packages. The condition in 
public universities can also be made worst by the possible lack of specific support from the public institutions with regards to expatriate management.

Majority of the expatriates join public universities with clear understanding of the limitations faced by the university. Nonetheless some accept the appointment and develop a high level of organizational commitment and move on to being contributing members to the university. However some expatriates leave the university to join private institutions which offer better pay and benefits. This is not only expected but also consistent with findings that expatriates willingness to accept longterm global assignments positively related to the compensatory rewards and benefits offered (Konopaske, Robie, \& Ivancevich, 2009). This is caused by the perception of greater risks associated to long-term global appointments whether it is from a personal, career or family point of perspective (Konopaske, Robie, \& Ivancevich, 2009). If the risks and costs of an international assignment is higher that remaining where they are, they are more unlikely to accept the assignment and just remain in the home country. From an organization's point of view, it would merely ensure that expatriates are "no worse off" financially than they would be if they stayed in the home country (Pate \& Scullion, 2010).

The absence of a clear understanding of the level of perceived organizational support of expatriates in public universities could have an effect on the strategic human resource management of the university and could also have an impact on the organizational commitment of expatriates. Perceived organizational support is capable of setting off a reciprocal effect. Expatriates with high perceived organizational support would reciprocate by exhibiting actions of commitment towards the University. Therefore universities that are aware of the level of perceived organizational support among its expatriates could use that knowledge as a basis of its strategic plans to ensure that the plans are viable.

\section{Literature Review}

\section{Organizational Commitment}

Organizational commitment is defined as a psychological state or mindset where an employee identifies with its organization and reflects a desire, a need, and/or an obligation to maintain membership with the organization (Blau \& Boal, 1987; George, Reed, Ballard, Colin, \& Fielding, 1993; Meyer \& Allen, 1991). Meyer \& Allen (1991) conceptualized organizational commitment into 3 components, i.e. affective commitment, continuance commitment and normative commitment. Each component will be discussed further in the following sections.

\section{Affective Commitment}

Meyer and Allen (1991) stated that affective commitment is when employees remain with an organization because they want to do so. Employees find themselves not only emotionally attached to the organization but also indentify with and are involved in the organization. As such affective commitment consists of personal characteristics, organizational structure and work experience (Meyer \& Allen, 1991).

In a study on prison employees found that the more control or autonomy the employees felt they had over their work environment, the weaker the effects of perceived organizational support had on the levels of affective commitment (Aube', Rousseau, \& Morin, 2007). Aube', Rousseau, \& Morin (2007) clarified that the level of control the employees feel could be either caused by their personality or the job designs itself which allows for more autonomy. The employees are able to perform their duties with minimal guidance or restriction from superiors or management. In such cases where there is a high level of work autonomy, organizations should focus on their support efforts in hope that it will 
stimulate and influence employees affective commitment (Gupta, Vohra, \& Bhatnagar, 2010; Aube', Rousseau, \& Morin, 2007).

High levels of affective commitment also have the potential of influencing employees to be more accepting of change in the organization. This is because employees with high levels of affective commitment not only have a better sense of identification with the organization but also demonstrate more involvement and are more emotionally attached to the organization and therefore are more open to accept change as long as the change initiative is seen as beneficial to the organization (Yousef, 2000).

Hence it is clear that organizational commitment is reciprocating in nature. It is based on the idea that commitment is a result of employees exerting more effort in exchange for rewards whether it is material or symbolic (Eisenberger e. al., 1986). Therefore, employees with higher perceived organizational support would be expected to show higher affective commitment. In cases of expatriates, it could be further argued that such support as better rewards, fair operating procedures and job conditions would influence both their perceived organizational support and organizational commitment and should therefore be adequately addressed by organizational leaders (Dawley, Andrews, \& Bucklew, 2008).

However in a study conducted on employees in the UAE found that even though the employees scored low satisfaction with pay, promotion and security aspects of their employment they still scored high affective commitment (Yousef, 2000). This finding helps to support Meyer and Allen (1991) argument that the reason behind deciding to remain in an organization may not be based solely of the cost associated with leaving but rather with the affective commitment the employee has towards the organization. Affective commitment does not only influence the retention of employees but also "seems to be the most beneficial facet of commitment for enhancing organizational effectiveness" (Tornikoski, 2011). Employees who exhibit high affective commitment feel a sense of attachment to the organization. They relate to the mission and vision of the organization. Therefore their commitment is not affected by the low satisfaction to pay, promotion or security. As a result, if public universities are capable of enhancing affective commitment among its expatriates, it would be expected to increase their organizational commitment and reduce the effects of low compensation satisfaction.

\section{Normative Commitment}

According to Meyer and Allen (1991), normative commitment refers to the feeling of obligation felt by employees to continue employment. As a result employees remain with the organization because they feel they should. Normative commitment can also be seen as resulting from the feeling of being indebted to an organization as a result of the organization presenting the employees with rewards in advance (Scholl, 1981). In the context of expatriate appointment in public universities, the fact that the university pays for their passage of entry to take up employment might be a contributing factor for increasing their normative commitment. Hence their commitment is based on the feeling that they have to remain with the organization until the debt is paid off.

Nevertheless Martin (2008) found that satisfaction and solidarity to some extent affected normative commitment of employees. Satisfaction on the duties and responsibilities demonstrated a significant negative influence on normative commitment. A possible reason for this could be found in the condition where employees who are satisfied in their job feels more emotionally connected to the organization and less obligated to work and consequently are more relaxed and feel that less effort is needed to maintain a good working relationship (Martin, 2008).

Contrastingly the opposite was found in the public sector. In a research conducted by 
Addae, Parboteeah, \& Velinor (2008) demonstrated that a negative relationship existed between normative commitment and role ambiguity and role conflict. Employees who demonstrated high levels of role ambiguity and conflict were less likely to have an emotional connection to the organization, identify with the values and goals of the organization or feel obligated to remain in the public sector (Addae, Parboteeah, \& Velinor, 2008). The research concluded that in the public sector organizations, could improve normative commitment of its employees by introducing interventions that lower role ambiguity and conflict.

\section{Continuance Commitment}

Continuance commitment is when an employee decides to remain in an organization because they need to (Meyer \& Allen, 1991). The need to remain with the organization could be a result of the employees' advancement within the organization which comes with tenure and the acknowledgement of the employees that they have contributed to the organization in terms of time and effort as well as the acknowledgement of increase the cost of leaving the organization (Currie \& Dollery, 2006). This supports the argument that continuance commitment actually reflects the acknowledgement of the costs related with leaving the organization. Hence anything that increases the perceived cost of leaving the organization would serve as influencing the level of continuance commitment (Meyer \& Allen, 1991).

Continuance commitment therefore depends highly on the employees' perception of the costs they are faced with. Should the cost of leaving the organization outweigh the cost of remaining with the organization, it would be expected that the employee would choose to remain with the organization. The cost evaluation could involve consideration on tenure and the position the employee holds as they might feel that they have invested too much to actually consider separating from the organization (Kwantes, 2009).

Consequently, several researches have shown that indeed continuance commitment is related to age and tenure (Currie \& Dollery, 2006; Kwantes, 2009). As an employee advances in terms of tenure, they begin to have the perception that they have invested their time, effort and knowledge which leads to a perception of increasing cost with regards to leaving the organization (Currie \& Dollery, 2006). It would be of interest to shed some light in the issue of continuance commitment and tenure especially so in the case of self-initiated expatriates such as in public universities in Malaysia. This is because they are free to move from one institution to another. They are not bind to a particular university and therefore mobility among expatriates at public universities is high. Consequently, the question to ask would be since they are so mobile, would they even exhibit continuance commitment? Wouldn't it be easier for them to leave the public university and join another university which is capable of offering them better pay packages?

Iles, Forster \& Tinline (1996) suggested that since continuance commitment was based on a sense of perceived cost benefit analysis it would not likely lead to high job performance. However, Suliman and Iles (2000) found that the higher the perceived cost of terminating employment with an organization, the higher the expected performance. This is because the employee would do whatever it takes to guarantee their place in the current organization. Expatriates would show higher performance to ensure their contract is renewed. Subsequently they "suggested that continuance commitment is a positive organizational phenomenon and that organizations should encourage it rather than discouraging its development in the workplace". It is possible that organizations increase commitment of their employees by increasing both intrinsic and extrinsic rewards and benefits to attract the 
employees and increase the perception of the costs incurred if they left the organization (Suliman \& Iles, 2000).

\section{Perceived Organizational Support}

Perceived organizational support is defined as the employees' global beliefs with regards to the extent to which the organization values their contributions and cares about their well-being (Eisenberger et. al., 1986). Perceived organizational support can be better understood by looking at it from the social exchange theory. Although social exchange theory got its roots from the theory of economic exchange it defers in the fact that the return, for the most part involves unspecified obligation. Even though there is a clear expectation of return, the exact nature of the return is not predetermined (Blau, 1964). Similarly employees tend to value returns or rewards from the organization. If the rewards and returns are based on the discretion of the organization it is seen as an indication that the organization genuinely values the employees' contribution and cares for their well-being (Dawley, Andrews, \& Bucklew, 2008; Rhoades \& Eisenberger, 2002).

Employees' perceived organizational support would actually be influenced by different aspects of the organization's treatment and consequently have the ability to influence how employees interpret the motives underlying the treatment by the organization (Eisenberger et. al., 1986). Therefore the support is expected to come from the organization as an entity. Rhoades \& Eisenberger (2002) argued that organizational leaders would have to seriously look into addressing organizational-supported policies and programs in an effort to preserve an acceptable level of perceived organizational support. It is also vital for organizations to realize that the support provided would extend beyond the limitations of work environment to include general adjustment, interaction adjustment (Kraimer, Wayne, \& Jaworski, 2001) and employee commitment to the organization (Aube', Rousseau \& Morin, 2007; Gupta, Vohra, \& Bhatnagar, 2010). This is because expatriate adjustment does not only depend on adjustment with the work environment but also with the cultural adjustment, community adjustment as well as the adjustment of expatriates' family to the new environment they face.

Expatriate adjustment to an extent includes spousal adjustment because the stress felt by the accompanying spouse can have damaging effects on the expatriates. Selmer \& Leung (2003) noted that the relationship between spousal adjustment and expatriate adjustment is indeed reciprocal and that previous researches have shown that spouses' inability to adjust in the host country is the most common reason for expatriate failure. This is because adjusting to a foreign culture and environment could be a long and painful undertaking. Therefore the support provided by the organization should extent to ease the adjustment of accompanying family. This can be more demanding if the accompanying spouse is the male spouse. This is because that male spouse lacks the social support female spouses get through their networks with other expatriate female spouses. In cases of expatriates in the public universities, this could include providing services and assistance to help acquire a suitable place to stay, assistance with school affairs of their accompanying children, providing counseling services and assistance dealing with the relevant authorities including the Immigration Department and the District Education Department.

Subsequently, Chen \& Eldridge (2011) also found that even though their study did not show a significant relationship between perceived organizational commitment and newcomer social integration, it did reveal a link between perceived organizational support and employees' intention to leave. This means that perceived organizational support is negatively related to newcomer's turnover intention. Therefore, organizations which want to retain its newcomers should 
put more effort on showing that the organization supports and cares about the newcomers' wellbeing. The same is also relevant in the public universities. After taking into consideration the investment put into recruiting the expatriates as well as taking into consideration the turnover costs involved if the expatriates decides to leave, it is therefore vital that the universities show the expatriates that it supports them and genuinely cares about their wellbeing. This would increase expatriates' trust on the university and ultimately guide them towards actions of performance and commitment.

With the benefits perceived organizational support has on employee commitment, it would make sense that all organizations focus on improving the perceived organizational support. However not all organizations are able and capable of providing high level of support to its employees. In cases such as this the organization could take some alternative actions. It could look at increasing work autonomy to compensate for the lack of support. Organizations could also reengineer the recruitment process to ensure candidates with internal locus of control are selected because these employees would be more capable of maintaining their affective commitment (Aube', Rousseau \& Morin, 2007).

\section{Relationship between Perceived Organizational Support and Organizational Commitment}

Organizational commitment of employees ultimately lies on the basis of trust. The trust an employee has towards the employer that they are genuinely concerned about their well-being. It is this trust that builds the relationship between affective commitment and perceived organizational support. An employee who is affectively committed to the organization increases their efforts as a result of the belief, trust and exchanged ideology that the organization will reciprocate their efforts with material and symbolic rewards (Eisenberger, et. al., 1986). Dawley, Andrews, and Bucklew (2008) found that perceived organizational support was the stronger predictor of organizational commitment even if compared to mentoring and supervisor support. This was explained by the social exchange theory. In this perspective, the social exchange theory argues that expatriates would evaluate the overall value of their relationship with the organization by subtracting its costs from the rewards it gets. The costs incurred would include the time and effort the expatriate puts in at the University. Whereas the reward would not only be monetary but would also include the support the University provides. If the support provided is more that the time and effort exerted, this would result in a positive relationship which is likely to translate to positive actions such as improved performance and higher commitment. Subsequently, perceived organizational support is valued more by employees if the support and rewards are based by the discretion of the organization itself and not based on external or internal influences such as unions or government regulations. This is because the organization is seen as genuinely caring about expatriates' wellbeing. Even mentoring and supervisor support could be construed as being influenced by personal agendas and ultimately valued less.

In a study to see the moderating effects of locus of control and work autonomy on perceived organization support and organizational commitment, Aube', Rousseau, and Morin (2007) found that the more control an employee feels or the more power they have over their work, the weaker the effect of perceived organizational support on their affective commitment. Therefore this study substantiates the importance of perceived organizational support as a stimulus for employees' affective and normative commitment (Aube', Rousseau \& Morin, 2007). It is argued that should employees perceive high organizational support, it would influence the increase of 
affective and normative commitment because it would be a sign of not only how much the organization trusts them but also values them. In another study by Gupta, Vohra, and Bhatnagar (2010) they found that autonomy negatively related to all the components of commitment and they concluded that organizations need to focus on their support efforts if it wanted to influence organizational commitment. All these studies corroborate Rhoades \& Eisenberger (2002) statement that perceived organizational support is positively related to affective commitment.

In a separate study conducted on police personal, Currie \& Dollery (2006) found that continuance commitment being true to its definition as a condition of cost benefit analysis was instead positively related with tenure. The longer the tenure, the more effort and time has been invested by the employee to the organization. Therefore, they exhibit higher continuance commitment since the costs of leaving the organization and adapting to a new environment would be less appealing than remaining with the current organization. The study also found support that affective commitment weakened as the employees had lower perceived organizational support. In looking at organizational commitment as an entire entity the study found that organizational commitment decreased as age, rank and years of service increased. This is because employees believe that the level of support provided by the organization decreases as the employee gains seniority.

The literature shows that of the three components of organizational commitment, affective commitment is the one component of major interest and is also the one component that has attracted the most studies. Jain, Giga, and Cooper (2008) concluded that wellbeing or organizational support "was found to be positively related with affective and normative commitment and negatively related with continuance commitment. Since continuance commitment is the condition where employees remain with the organization because they feel they need to, higher organizational support would reduce the feeling of needing to remain with the organization and increase the decision to remain with the organization because they want to or that they feel they ought to. Nevertheless, coverage on normative and continuance commitment has been rather lacking. The lack of coverage of normative and continuance commitment could be as a result of the value or impact it is seen to have on organizations. Normative commitment is a condition where employees remain in an organization because they feel they are obligated to do so and continuance commitment is a condition where employees remain because they do not have any other cost effective option, both conditions do not seem to have an effect on organizational effectiveness and are unlikely to lead to high job performance (Suliman \& Iles, 2000). Employees with normative and continuance commitment are more likely to contribute less so long as they get the rewards they believe are due. As such research has been focusing on affective commitment, what affects it and how can it be influenced and increased. Nevertheless Suliman and Iles (2000) suggests that continuance commitment should be encouraged in organizations since it is a positive occurrence since the overall commitment is of greater value.

\section{Research Framework \& Methodology}

Based on the review of the literature, it is indicated that perceived organizational support predictorganizational commitment. Figure 1 show the framework of this study. 


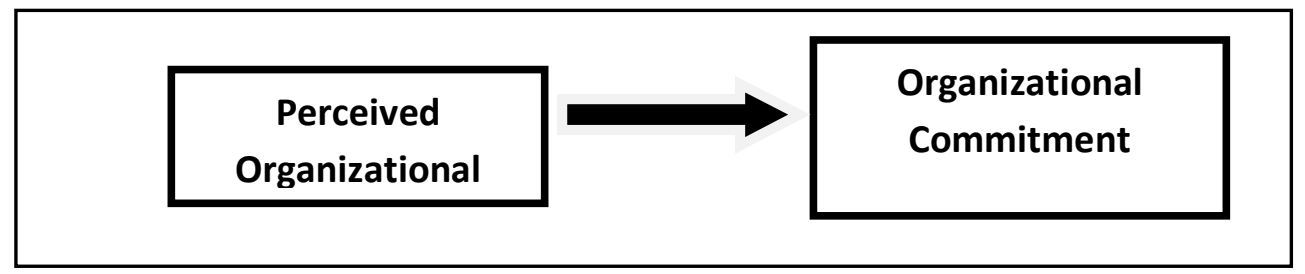

Figure 1: Research Framework on the Relationship between Perceived Organizational Support and Organizational Commitment

\section{Samples}

The population of this study is the 131 expatriate who are currently serving the institution at various faculties. The hard copy versions of the survey were distributed to the sample. From the total sample of 131, only 108 responses were collected. Fifteen responses were rejected due to partial responses. Therefore the final number of responses used for further analysis was 93. This signifies a response rate of $70.99 \%$.

\section{Respondents}

The 93 respondents comprised of 77 (82.8\%) were male expatriates and $16(17.2 \%)$ were female expatriates. 44 (47.3\%) respondents aged from 30 - 40 years old, 25 (26.9\%) aged from 41 to 50 years old, 16 (17.2\%) were between 51 to 60 years old and the remaining $8(8.6 \%)$ respondents were above 61 years old. Respondents with tenures of less than 3 years and 4 to 6 years were 35 (37.6\%) respectively. Fourteen (15.1\%) respondents have been working at the University for 7 - 9 years and the remaining $9(9.7 \%)$ respondents have been with the University for 10 years or more. The positions of the respondents were equally distributed between lecturer, senior lecturer and associate professor where 28 (30.15\%) respondents are lecturers, 29 (31.2\%) senior lecturers and $29 \quad(31.2 \%)$ associate professors. Only 7 (7.5\%) respondents are professors.

\section{Measurements}

The instrument used to evaluate organizational commitment was that of
Meyer \& Allen (1993). Meyer \& Allen (1993) Three-Component Model Employee Commitment Survey measures all three dimension of organizational commitment which are affective commitment, normative commitment and continuance commitment. The survey has six items for each dimension compared to the earlier version which had eight items for each component (Meyer \& Allen, 1990). The survey requires the subjects to provide responses based on their perception of their relationship with the organization using a seven-point Likert scale from 1 denoting strongly disagree to 7 denoting strongly agree. These items were widely used in previous empirical studies with a consistent reliability result of 0.88 .

For Perceived Organizational Support measures, 16-item Survey by Rhoades \&Eisenberger (2002) were utilized. All responses were on 7-point Likert scale and ranged from (1) 'Strongly disagree' to (7) 'Strongly agree'.

\section{Data Analysis}

Reliability tests for the independent and dependent variables were conducted. Subsequently,correlation and regression analyses were conducted to examine the relationship between perceived organizational support and organizational commitment.

\section{Results}

Table 1 shows the reliability results, means and standard deviation of the variables. The results exhibit thatthe reliability result were greater than 0.70 indicating reliable value for 
all the dimensions of the instruments. Generally, the results also exhibited mean values of 4.83 to 4.91. Further, the Cronbach's alpha value for perceived organizational support and organizational commitment were $\quad 0.86$ This demonstratesthat the variables understudy have good reliability coefficient values, which are all above the lower limit of acceptability of 0.6 .

Table 1: Reliability, Means and Standard Deviation of the Study Variables

\begin{tabular}{|l|c|c|c|}
\hline \multicolumn{1}{|c|}{ Items } & A & Mean & Std. Deviation \\
\hline Perceived Organizational Support & 0.86 & 4.83 & .99 \\
\hline Organizational Commitment & 0.86 & 4.91 & .97 \\
\hline & & & \\
\hline
\end{tabular}

$\mathrm{n}=93,{ }^{* *} \mathrm{p}<.01 ; \alpha=$ alpha results, $\mathrm{M}=$ mean, $\mathrm{SD}=$ standard deviation

The correlation results indicated that perceived organizational supportwere associated with organizational commitment. There were positive and significant relationships between perceived organizational support with organizational commitment $(\mathrm{r}=.62)$, and its dimensions of affective commitment ( $\mathrm{r}=.73)$, normative commitment $(\mathrm{r}=.61)$,. However, calculative commitment does not correlate with perceived organizational support.

Table 2: Correlation Results of HRM Practices and Employee Engagement

\begin{tabular}{|l|l|l|l|l|l|l|}
\hline & 1 & 2 & 3 & 4 & 5 & 6 \\
\hline 1. Perceived Org Support & 1 & & & & & \\
\hline 2. Organizational Commitment & $.62^{* *}$ & 1 & & & & \\
\hline 3. Affective Commitment & $.73^{* *}$ & $.87^{* *}$ & 1 & & & \\
\hline 4. Normative Commitment & $.61^{* *}$ & $.88^{* *}$ & $.78^{* *}$ & 1 & & \\
\hline 5. Calculative Commitment & .05 & $.58^{* *}$ & .18 & $.26^{* *}$ & 1 & \\
\hline$* * \mathrm{p}<.05$
\end{tabular}

To determine if perceived organizational support influencedorganizational commitment, regression analysis was performed. Table 3 indicated that $40.6 \%\left(\mathrm{R}^{2}\right.$
$=0.406$ ) of the variance in organizational commitment had been significantly explained by perceived organizational support.

Table 3: Results of Multiple Regression of Perceived Organizational Support and Organizational Commitment

\begin{tabular}{|l|l|c|c|c|c|c|}
\hline & \multicolumn{2}{|c|}{$\begin{array}{c}\text { Unstandardized } \\
\text { Coefficients }\end{array}$} & $\begin{array}{c}\text { Standardized } \\
\text { Coefficients }\end{array}$ & & \\
\hline & & B & Std. Error & Beta & t & Sig. \\
\hline & (Constant) & 1.843 & .402 & & 4.588 & .000 \\
\hline & Perceived Org Support & .500 & .109 & .500 & 4.580 & .000 \\
\hline & & & & & \\
\hline R Square $=.406$ \\
\hline F $=30.353$
\end{tabular}




\section{Discussions and Implications}

The correlation results revealed that the relationship between perceived organizational support and affective commitment is significantly correlated $(\mathrm{r}=$ $0.73, \mathrm{p} \leq 0.01$ ). The results also showed that perceived organizational support and normative commitment is also positively correlated $(r=0.61, p \leq 0.01)$. However the relationship between perceived organizational support and continuance commitment is not correlated at $\mathrm{r}=0.05$.

The relationship between perceived organizational support and affective commitment is based on trust that the University genuinely cares about expatriates' well-being. Employees who are affectively committed to the organization are expected to increase their efforts as a result of the belief that their efforts will be rewarded or reciprocated (Eisenberger, et. al., 1996). Therefore, expatriates who perceive that they are getting support from the University would influence their affective commitment. This is because they would be able to relate to the University and value the University's vision and mission. They would feel as though they are part of the University.

This feeling of trust would also influence normative commitment. When the expatriates feel that they are getting the support from the University and the belief that the University is genuine in caring for their wellbeing, they would reciprocate with actions of commitment and high job performance. The expatriates would feel that they owe the University their commitment in repayment for the University's support.

Hence, it is recommended for the organization to increase efforts of organizational support. Therefore there is a need for the University to increase its efforts on providing support to its expatriates if it wishes to increase the level of affective commitment among the expatriates. Such efforts could include the introduction of a specific unit responsible for the management of expatriates at the University which could serve as a one stop center to assist them with all their needs. In addition, increase communication on the support efforts the University has for its expatriates. Expatriates are currently managed at Faculty level therefore giving them the perception that it is the Faculty that cares about their well-being and not the University. This has resulted in expatriates expressing that there are differences in level of commitment between faculty and the University. This would result in expatriates' interpreting that the support is only coming from the faculty and not the University. Should the management of the faculty change in its practices of managing its expatriates it could alter expatriates commitment level which could have a devastating effect on the University. In addition, to improve normative commitment of expatriates by introducing interventions directed at lowering role ambiguity and conflict. Being a public university, there are limitations to the type of support the University is capable of providing. In such cases previous research has shown that increasing work autonomy could compensate for the lack of organizational support (Aube', Rousseau \& Morin, 2007).

\section{Conclusion}

This study has successfully answered the objective, which is to examine the relationship between perceived organizational support and organizational commitments of expatriate. From the regression results, it was found that perceived organizational support had a strong predicting role in determining organizational commitment. This finding has provided a better understanding of the relationship of these variables in order to enhance and improve managerial effectiveness of the expatriate. Hence, there is a need to constantly improve the existing human resource practices at the organization, particularly in enhancing organizational commitment. The results of the study have also given some inputs to human resource professionals in designing 
more favorable policies and procedures that can help improve expatriate management in the organization.

\section{References}

Addae, H. M., Parboteeah, K. P. \& Velinor, N. (2008). "Role Stressors and Organizational Commitment in St Lucia," International Journal of Manpower, 29(6), 567 - 582.

Aube', C., Rousseau, V. \& Morin, E. M. (2007). "Perceived Organizational Support and Organizational Commitment: The Moderating Effect of Locus of Control and Work Autonomy," Journal of Managerial Psychology, 22(5), 479-495.

Bishop, J. W., Scott, K. D., Goldsby, M. G. \& Cropanzano, R. (2005). "A Construct Validity Study of Commitment and Perceived Support Variables: A Multifocal Approach across Different Team Environments," Group \& Organization Management, 30(2), 153-180.

Blau, G. J. \& Boal, K. B. (1987). "Conceptualizing How Job Involvement and Organizational Commitment Affect Turnover and Absenteeism," Academy of Management Review, 12(2), 288-300.

Blau, P. M. (1964). Exchange and Power in Social Life, New York: John Wiley and Sons Inc.

Boles, J., Madupalli, R., Rutherford, B. \& Wood, J. A. (2007). "The Relationship of Facets of Salesperson Job Satisfaction with Affective Commitment," Journal of Business and Industrial Marketing, 22(5),311-321.

Chen, J. \& Eldridge, D. (2011). "The Missing Link in Newcomer Adjustment: The Role of Perceived Organizational Support and Leader-Member Exchange," International Journal of Organizational Analysis, 19(1), 71 88.
Chew, J. \& Chan, C. C. A. (2008). "Human Resource Management, Organizational Commitment and Intention to Stay," International Journal of Manpower, 29(6), $503-522$.

Civil Service Department of Malaysia (2002). Pekeliling Perkhidmatan Bilangan 4 Tahun 2002, Pelaksanaan Sistem Saraan Malaysia Bagi Anggota Perkhidmatan Awam Persekutuan.

Currie, P. \& Dollery, B. (2006). "Organizational Commitment and Perceived Organizational Support in the NSW Police," Policing: An international Journal of Police Strategies \& Management, 29(4), 741-756.

Dawley, D. D., Andrews, M. C. \& Bucklew, N. S. (2008). "Mentoring, Supervisor Support, and Perceived Organizational Support: What Matters Most?," Leadership \& Organization Development Journal, 29(3), 235-247.

Day, N. E. (2011). "Perceived Pay Communication, Justice and Pay Satisfaction," Employee Relations, 33(5), 476 - 497.

Eisenberger, R., Huntington, R., Hutchison, S. \& Sowa, D. (1986). "Perceived Organizational Support," Journal of Applied Psychology, 71(3), 500-507.

George, J. M., Reed, T. F., Ballard, K. A., Colin, J. \& Fielding, J. (1993). "Contact with AIDS Patients as a Source of Work-Related Distress: Effects of Organizational and Social Support," Academy of Management Journal, 36, 157-171.

Gunlu, E., Aksarayli, M. \& Perçin, N. S. (2010). "Job Satisfaction and Organizational Commitment of Hotel Managers in Turkey," International Journal of Contemporary Hospitality Management, 22(5), 693-717. 
Gupta, M. A., Vohra, N. \& Bhatnagar, D. (2010). "Perceived Organizational Support and Organizational Commitment: The Mediational Influence of Psychological WellBeing," Journal of Business and Management, 16(2), 105-124.

Hassan, A. \& Hashim, J. (2011). "Role of Organizational Justice in Determining Work Outcomes of National and Expatriate Academic Staff in Malaysia," International Journal of Commerce and Management, 21(1), 82-93.

Heneman III, H. G. \& Schwab, D. P. (1985). "Pay Satisfaction: Its Multidimensional Nature and Measurement," International Journal of Psychology, 20, 129-141.

Iles, P. A., Forster, A. \& Tinline, G. (1996). "The Changing Relationship between Work Commitment, Personal Flexibility and Employability: An Evaluation of a Field Experiment in Executive Development," Journal of Managerial Psychology, 11, 18 - 34.

Jain, A. K., Giga, S. I. \& Cooper, C. L. (2009). "Employee Well-Being, Control and Organizational Commitment," Leadership and Organizational Development Journal, 30(3), 256-273.

Konopaske, R., Robie, C. \& Ivancevich, J. M. (2009). "Managerial Willingness to Assume Travelling, Short-Term and Long-Term Global Assignments," Management International Review, 49(3), 359-387.

Kraimer, M. L., Wayne, S. J. \& Jaworski, R. A. (2001). "Sources of Support and Expatriate Performance: The Mediating Role of Expatriate Adjustment," Personnel Psychology, 54(1), 71-99.

Lam, T. \& Zhang, H. Q. (2003). “Job Satisfaction and Organizational Commitment in the Hong Kong Fast Food Industry," International Journal of Contemporary Hospitality Management, 15(4), 214-220.
Lee, H. W. (2005). 'The Factors Influencing Expatriates,' Journal of American Academy of Business, 6(2), 273-278.

Louis, M. R. (1980). "Surprise and Sense Making: What Newcomers Experience In Entering Unfamiliar Organizational Setting," Administrative Science Quarterly, 25, 226 251.

Martin, S. S. (2008). "Relational and Economic Antecedents of Organizational Commitment," Personal Review, 37(6), 589608.

Meyer, J. P. \& Allen, N. J. (1991). “A ThreeComponent Conceptualization of Organizational Commitment," Human Resource Management Review, 1(1), 61-89.

Ministry of Higher Education, (2007). Pelan Strategik Pengajian Tinggi Negara Melangkaui Tahun 2020, (Publication No. ISBN 978-983-3663-09-05). Retrieved January 5, 2010, from MoHE Web site: http://www.mohe.gov.

my/portal/images/utama/penerbitan/psptn .pdf.

Office of the Prime Minister of Malaysia (2009). Ucapan Bajet Tahun 2009, Retrieved August 5, 2011, from PMO Web site: http://www.pmo.gov.my/ ucapan $/$ ?m=p\&p=paklah\& id = 3196

Office of the Prime Minister of Malaysia (2010). Ucapan Bajet Tahun 2010, Retrieved August 5, 2011, from PMO Web site: http://www.pmo.gov.my/?menu $=$ speech $\&$ page $=1676 \&$ news_id $=172 \&$ speech_cat $=2$

Office of the Prime Minister of Malaysia (2011). Ucapan Bajet Tahun 2011, Retrieved August 5, 2011, from PMO Web site: http://www.pmo.gov.my/?menu=speech\&pa ge $=1676 \&$ news_id $=347 \& \quad$ speech_cat $=2$ 
Osahagbemi, T. (2000). "Correlates of Pay Satisfaction in Higher Education," The International Journal of Education Management, 14(1), 31 - 39.

Pandiyan, V. \& Chandran V. G. R. (2009). "Research Methods: A Simple Guide for Business Undergraduates," Selangor: University Publication Centre (UPENA), UiTM.

Pate, J. \& Scullion, H. (2010). “The Changing Nature of the Traditional Expatriate Psychological Contract," Employee Relations, 32(1), 56-73.

Rhoades, L. \& Eisenberger, R. (2002). "Perceived Organizational Support: A Review of the Literature," Journal of Applied Psychology, 87(4), 698-714.

Sekaran, U. \& Bougie, R. (2010). Research Methods for Business: A Skill Building Approach, United Kingdom: John Wiley \& Sons Ltd.

Selmer, J. \& Leung, A. S. M. (2003). "Provision and Adequacy of Corporate Support to Male Expatriate Spouses, an Exploratory Study," Personnel Review, 32(1), 9 - 21.

Tornikoski, C. (2011). "Fostering Expatriate Affective Commitment: A Total Reward Perspective," Cross Cultural Management: An International Journal, 18(2), 214 - 235.

Williamson, I. O., Burnett, M. F. \& Bertol, K. M. (2009). "The Interactive Effect of Collectivism and Organizational Rewards on Affective Organizational Commitment," Cross Cultural Management: An International Journal, 16(1), 28 - 43.

Yousef, D. A. (2000). “Organizational Commitment and Job Satisfaction as Predictors of Attitude toward Organizational Change in a Non-Western Setting," Personnel Review, 29(5), 567-592. 